\title{
Global Administrative Law and Regulation of Extraction of Minerals in Outer Space
}

\author{
Alexander Zyma \\ Ph.D., Associate Professor, Yaroslav Mudryi National Law University \\ (Kharkiv, Ukraine) \\ E-mail: zima_ot2@ukr.net \\ https://orcid.org/0000-0003-4937-871X
}

\begin{abstract}
Entrepreneurship is one of the areas of space exploration. The steadily growing number of types of space entrepreneurship, the risk increases that some of them will remain outside the legal framework. The aim of the study is to analyse the state of affairs in legal regulation of extraction of minerals in outer space, evaluate its shortcomings and propose new means of regulating this type of business relations. The authors hypothesize that it is expedient to exercise legal regulation of extraction of minerals on celestial bodies and their import to Earth by the provisions of global administrative law. In addition, it is proposed to create a global administrator of space resource relations. It should be provided with a set of legal means that will ensure regulation of social relations in this field to avoid threats to the world market from the uncontrolled supply of space resources to Earth.
\end{abstract}

Keywords: mineral deposits; space entrepreneurship; global administrative law

Received: September 01, 2019; accepted: October 07, 2019

Advanced Space Law, Volume 4, 2019: 125-136.

https://doi.org/10.29202/asl/2019/4/12

\section{Introduction}

The first space object (Elementary Satellite-1) was launched into outer space by the Soviet Union on October 4, 1957. This date can be considered the beginning of active exploration of space by man. The importance and significance of space activities for all humanity required its legal regulation at the international level. In 1959, the UN Committee for the Peaceful Uses of Outer Space was established and it is still in force. Its legal subcommittee has played and continues to play an important role in shaping international space law. The basic international instrument to regulate space relations is the Treaty on Principles Governing the Activities of States in the Exploration and Use of Outer Space, including the Moon and Other Celestial Bodies of 12 January 1967 (hereinafter the Outer Space Treaty). Ukraine is one of the first States to ratify it. It happened on May 22, 1967.

Since 1957, space exploration and space activities have been conducted in two different areas. First, it is activities related to space exploration. Second, these are various forms of

(C) Zyma, Alexander, 2019. 
military activities. Accordingly, the vast majority of the legal provisions enshrined in the Outer Space Treaty regulate relations formed during scientific and military activities in outer space: some of these provisions restrict the military use of space to some extent and the other encourage cooperation in research activities. In addition, the Treaty contains provisions governing specific practical issues of space exploration (defines the principles of jurisdiction over space objects, establishes the procedure for compensation for damage caused by space activities, establishes obligations to assist astronauts, etc.)

However, in a little while the third area of space activities began to form, which is space entrepreneurship, entrepreneurship in outer space or the use of space for commercial purposes. The Outer Space Treaty never explicitly mentions the possibility of this space activity, but does not impose any prohibition on it. Therefore, the International Organization of Space Communications "Intersputnik" of November 15, 1971 refers to the commercial use of the space communication system by means of the space complex (Article 5) and the procedure for distribution of profits that may be obtained from such commercial use between the members of the organization (paragraph 9 of Article 15). The subjects of commercial activity are States, but this does not change its essence.

\section{Directions for the use of outer space for commercial purposes}

Total entrepreneurship in outer space is constantly growing, though not very fast. Now it is possible to mention the presence of the areas (types) of the use of outer space for commercial purposes: (a) commercial satellite communication; (b) commercial satellite television; (c) commercial use of satellite land remote sensing; (d) commercial use of global satellite navigation; (e) space research (experiments) for commercial purposes; (e) etc. They all are about the use of spacecraft, mainly satellites, to provide high-tech services related to the collection, processing and transmission of information. For a long time, the term "space technology" is used to refer to the latest, high-tech developments of guaranteed quality. Frequently, States or their bodies continue to be the subjects carrying out commercial projects.

Recently, however, there have been significant changes in the use of outer space for commercial purposes. The results of scientific research and technological development enables to "materialize" it. As mentioned above, until recently space entrepreneurship has focused solely on providing sophisticated information services to consumers and individuals of Earth. At present, a commercial activity related to tangible objects in outer space starts. First, it is the services of moving such objects in space, as well as importing and exporting them beyond Earth.

The beginning of this process should be identified with the emergence and development of space tourism. Contrasting others, this type of entrepreneurship is not related to the transfer or processing of information, but involves the paid transfer of an individual in space. The payment is very high that is why there have been only about 10 people to use tourist service for 19 years. Due to the limited interest in the phenomenon, legal regulation of space tourism at the international level has not taken place. At present, issues related are governed by the legal regulations of national law, using the specific provisions of international treaties. However, tourism in outer space is developing, gradually "pulling" other types of terrestrial entrepreneurship. For example, Orion Span plans to launch the first space hotel in late 2021. However, over the next 50 years, the impact of space tourism may not have a significant impact on the world economy. 
Another matter is the extraction of material resources (minerals, water, etc.) from the moon and other celestial bodies. At present, minerals are not extracted outside our planet, but scientific developments aimed at ensuring the implementation of such activities are at the final stage. The authors will not study this problem further, however, it should be noted that Planetary Resources, Moon Express, SpaceX, Blue Origin and other, mainly American, companies are concerned with the development of space exploration technologies. The Grand Duchy of Luxembourg has provided the space industry with ideal terms and significant investments at the State level [Luxembourg, 2019].

\section{Extraction of minerals on celestial bodies as a space business}

From a legal perspective, the extraction of minerals on celestial bodies and in outer space requires a considerable number of complex issues to be solved. This is due to the absence of special international legal treaty that would regulate space entrepreneurship in general and mining in outer space in particular. With regard to the basic document of space law, the Outer Space Treaty, the rules of its provisions are contradictory leading to more confusing than solving the problems. For example, Article 2 provides for that outer space, including the moon and other celestial bodies, is not subject to national appropriation by claim of sovereignty, by means of use or occupation, or by any other means. However, outer space shall be free for exploration and use by all States without discrimination of any kind, on a basis of equality, and there shall be free access to all areas of celestial bodies (Part 2 of Article 1). Comprehensive analysis of Articles 6 and 7 indicates that the use of outer space can be carried out both by the State itself and by private legal entities registered therein (in the Treaty referred to as "nongovernmental entities"), whereby the State bears some responsibility for the activities of such legal entity.

The authors argue that in the context of the study, these provisions should be interpreted as follows: governmental agencies and private entities may carry out the exploitation and extraction of minerals in outer space with the permission and under the supervision of the State, therein they are incorporated. Despite the fact that no sovereignty of the curatorial State extends to the territory of the celestial bodies where the minerals are mined, but only its permission. However, this position contradicts the Preamble and Part 1 of Article 1 of the Treaty, according to which the use of outer space, including the moon and other celestial bodies, shall be carried out for the benefit and in the interests of all countries, irrespective of their degree of economic or scientific development, and shall be the province of all mankind. In relation to commercial extraction of minerals from the celestial body, the state of affairs reveals that outer space, in particular the interior of the celestial body, is used in the commercial interests of an individual State or its private legal entity due to their economic and scientific dominance over other countries and may cause some harm to humanity.

Primarily, the potential harm to humanity means that transporting to Earth certain, less common ("rare-earth") and other, more common, elements for commercial purposes can lead to uncontrolled and unpredictable changes in the markets of mineral deposits, significantly affecting the course of economic processes and causing severe crises in different economic sectors. This thesis can be confirmed by the following calculation. According to the World Bank, the total gross product of planet Earth was about USD 85 trillion [GDP, 2019]. At the same time, according to John Lewis, professor of astronomy at the University of Arizona, the estimated value of resources that can be mined on a single asteroid (3554), $2.5 \mathrm{~km}$ in diameter, 
is about USD 20 trillion (one quarter of the world gross product in 2018): USD 8 trillion iron and nickel, USD 6 trillion - cobalt, USD 6 trillion - platinum and other platinum group metals [Khvostik, 2018]. That is, the value of one asteroid will far exceed the value of all mineral deposits sold for a year in the world. It is impossible to foresee and predict the effects of the resources inflow from other planets to Earth, since no analogues have happened in the world history. A long way off is the bankruptcy of Spain, caused by the importation of gold from the New World.

However, the resource exploitation in space is a progressive phenomenon, and progress cannot be stopped by prohibitions and restrictions. Therefore, the space mining activities require regulation so that it does not lead to the collapse of the world economy and provides a positive effect not only for the individual producer, but also for all humanity. There are a number of important issues to address, such as:

- who has the right to extract minerals in space;

- which permit document provides grounds for such activities to be carried out; who and in what order issues this document;

- who and how controls the resource exploitation in space;

- what instruments are in place to protect the earth's resource markets from "space dumping";

- in what manner the positive impact of the space mining industry on the entire Earth's population is ensured.

It should be emphasized that the regulation of mining outer space resources is an extremely serious challenge for the international community. This is due to its possible significant global effects, both positive and negative.

At first glance, it seems obvious that the regulation of relations aimed at protecting the interests of all countries of Earth, and humanity as a whole, shall be governed by legal rules enshrined in international instruments. To authorize individual States to resolve them is not appropriate, since there is a high risk that the latter will be governed by national, before all economic and security, interests, and then by interests of other countries and the planet Earth community.

However, is it objectively possible to adopt international treaties that would address space commerce? It is doubtful due to the following. As mentioned above, more than 100 States have ratified the basic international treaty on space activities, the Treaty on Principles Governing the Activities of States in the Exploration and Use of Outer Space, including the Moon and Other Celestial Bodies of 12 January 1967. In thirty countries, this Treaty has been signed and not ratified.

The Convention on International Liability for Damage to Space Objects was ratified in 1972 by 89 countries only, and a few more were signed and not ratified.

The 1974 Convention on Registration of Objects Launched into Outer Space was ratified by even fewer states, 64 in total.

In 1979, the Agreement Governing the Activities of States on the Moon and Other Celestial was approved, which, by the way, could address a number of issues regarding extraction of outer space minerals. However, in 40 years, only 16 (!!!) States have ratified this Agreement.

Therefore, the authority of international acts regulating legal relations in space activities is not too high. The reluctance of particular States to accept restrictions in a promising and attractive (including commercially) area is evident.

Consequently, there was an attempt to regulate public relations in space mining by national law. In 2015, the United States adopted the Commercial Space Launch Competitiveness Act, 
which formally and unequivocally legalized the possibility of extracting minerals in outer space (on celestial bodies) by private companies and securing property rights of mineral deposits extracted.

This initiative has caused global community's controversy. For example, at the meetings of the UN Committee on the Peaceful Uses of Outer Space, the view was expressed that the adoption of such a law is an American way of unilaterally violating international space law [A/AC.105/C.2/2016/TRE/L.1., 2016]. A number of legal scholars have come to similar conclusions. They argue that the Outer Space Treaty provided the basic principles of international space law, and the US violated these principles [Oduntan, 2015; Benett, 1988; de Selding, 2015]. While no unity exist in regards to which principles are violated, the conclusions are based on a private interpretation of certain provisions of the Outer Space Treaty. Their opponents disagree. They mostly argue that the adoption of the Law does not contradict the provisions of the Treaty, but harmoniously develops them and fills the gap that come from unregulated private rights and interests in the process of space exploration [Masson-Zwaan \& Richards; Rummel, 2015; Koerth-Baker, 2015]. Moreover, their statements are based on private text interpretations of the main source of space law.

The authors will not participate in the discussion, but note that it is based on legal speculation around the provisions of a legal regulation substantially outdated. Moreover, another factor is important. Obviously, the US Commercial Space Launch Competitiveness Act has ushered in an era of national regulation of commercial mining activities in outer space. In 2017, a similar law was adopted by the Grand Duchy of Luxembourg. The adoption of similar laws by other spacefaring nations is a matter of time.

Therefore, the intermediate conclusions are:

First, the beginning of extraction of minerals in outer space is a matter of the coming decade.

Second, this type of activities should be regulated in detail to prevent uncontrolled effects on planet Earth's economy.

Third, the space mining industry regulation by the rules of international law is almost impossible, due to the lack of spacefaring nations' concern.

Fourth, the space entrepreneurship regulation by national law can lead to a state of affairs that activities in outer space, common to all humankind, will be regulated by each State independently, contrary to the provisions of other States.

\section{The place and role of global administrative law in space mining}

Therefore, it is precisely in this critical situation, the concept of global administrative law can be applied. By definition, global administrative law is a combination of legal rules, principles and institutional norms applicable to the administration process, related to more than purely national structures of legal and political authority. Professors Kingsbury and Donaldson emphasize that its specificity is that this law is the framework for administering within what might be thought of as a global administrative space, the existence of which contributes to blurring of national and international, public and private dimensions [Kingsbury \& Donaldson, 2011]. Sometimes, global administrative law is placed in an area governed by administrative law outside the state [López, 2018]. This is phenomenon in our case. Victoriya Pugach argues that within the concept of global administrative law, administrative activity can be implemented outside national regulatory framework, while the status of administrative 
bodies can be acquired by global and transnational institutions [Pugach, 2019: 76]. This is fully consistent with the challenges that space entrepreneurship poses to humanity.

Legal regulation of mineral extraction in outer space should begin in the absence of any experience, based on projections and assumptions. Certainly, the space resources law regulations, adopted for the first time, will contain a significant number of flaws and shortcomings, and will require constant changes and clarifications. The amendments can be ensured only through a specially authorized entity, the global space resources administration body. Here it would be appropriate to mention the opinion of Georgios Dymitropulus. In his work, he argues that contrary to the traditional (national) understanding of administration, global administration is largely a rule-making activity [Dimitropoulos, 2011]. In this case, granting a global space resources administration body with sufficient rulemaking authorities will ensure dynamism and effective regulation, unachievable if an international treaty is applied.

This body can be formed in different ways: on the basis of an international treaty, on the basis of an intergovernmental agreement of spacefaring nations, as a UN agency, like the World Postal Union, as an open association of entities engaged in the mining industry in space, as an association under the aegis of international organization, etc.

It is particularly attractive to establish this global administrator on the basis of, or having regards to the work of the Hague Space Resources Governance Working Group. This body is international. It was founded on December 1, 2014 by the results of a roundtable at the Hague Institute for Global Justice. The roundtable was attended by experts from many countries around the world, moreover, representatives of the leading companies of the space and aerospace industry took an active part in the work. Many of them are part of this group, which is focused on stimulating the process of international legal settlement of the extraction of resources in outer space [A/AC.105/C.2/2018/CRP.18., 2018].

Nowadays, the Hague International Space Resources Governance Working Group continues work and it has already proposed the Draft Building Blocks for the Development of an International Framework on Space Resources Activities [Draft, 2018]. This act is purely advisory. According to its analysis by Russian researcher Svetlana Popova, it is interrelated with the US and Luxembourg legal provisions mentioned above, moreover, the purpose of the Draft is to legalize the economic feasibility of commercializing space resources activities, supported by a number of States, which involves the realization of the principle of freedom of access to these resources and the property right of extracted or manufactured in situ in space [Popova, 208: 170].

This is confirmed by one of the participants of the Hague Working Group, English businessman Hunter-Scallion. He argues that the shortcomings of the legal framework on space resources activities have already become noticeable, and in this case, they should be addressed not only by lobbying for the adoption of the law on mining in space in the UK, but also in the international arena [GDP, 2019].

However, the implementation of this approach, as well as other options for international legal settlement of the problem seems unpromising. In addition, the Draft Building Blocks for the Development of an International Framework on Space Resources Activities mentions the appropriateness of forming an international body or bodies whose powers, however, are of a purely decorative nature. For example, another international non-functional bureaucratic body is being formed. Nevertheless, the Hague Working Group continues to work and it may reconsider its positions. 
Therefore, it would be appropriate to empower a global space-resource administrator with regulatory authority.

With regard to the authorities to issue permits for the exploitation of minerals in outer space, registration of entities, engaged in entrepreneurial activity in this area, and the space objects through which such activity is carried out, they may be transferred to national agencies, provided that the latter will apply the legal rules of global administrator acts in their permitting and registration activities.

This approach will reduce the resistance of spacefaring nations against the creation of a global administrator and against the introduction of global regulation.

In its activities, the global administrator can use a variety of public administration mechanisms. For example, one of the well-known mechanisms traditionally used to protect domestic markets and ensure economic development is the customs policy and customs in which this policy is implemented. Now the Space Customs Law does not exist. This is because the subject matter of legal regulation is objectively absent. As it is known, customs law regulates public relations regarding the movement of goods across the customs border. These goods must be tangible objects. So far, tangible objects from celestial bodies have been brought to Earth quite rarely. The last time a major "import" operation was carried out by the Luna-24 space station in 1976. On the Internet, a photocopy of a customs declaration filed by American astronaut Neil Armstrong upon his return from the moon in 1969 can be easily found. Whether this document is original or one of the widespread fakes, it is unknown, but it is obvious that the return of the American expedition to Earth from another celestial body was one of the few cases where customs law was able to get involved in regulating space relations.

The reasons for this are as follows. In accordance with international agreements and law application, state sovereignty extends to the airspace delineated vertically through the state border. The upper boundaries of the airspace of the State remain unclear. There are various proposals for the "roof" of the country. Most of them are about 90 to $110 \mathrm{~km}$ above sea level. Though it seems paradoxical, the vertical limit of state sovereignty is undeniable even in the absence of a relevant international or national international-legal act. This is due to objective physical processes, namely the constant movement of planet Earth in outer space. Accordingly, airspace under the jurisdiction of the State, airspace that is not under the jurisdiction of any of the States and outer space have different legal regimes.

The movement of goods across the customs border, which almost coincides with the State one and its import into the customs territory of the State, is regulated by customs law. However, it should be considered that the State party to the Outer Space Treaty, on whose registry an object launched into outer space is carried shall retain jurisdiction and control over such object, and over any personnel thereof, while in outer space or on a celestial body. The rule is not stated quite clearly, but since space has not been engaged in manufacturing and trading activities for now, the law practice identifies the space object with the State territory. Accordingly, it is of no interest to the customs authorities in the event of its return to land.

It is a different matter when an item (tangible object), which is not contained in a space object when it is launched from Earth, is brought to our planet. The territory of the moon and other celestial bodies is not part of the territory of any of the States of the world. Accordingly, a tangible object imported from another celestial body to planet Earth is a commodity that moves across the customs border to the customs territory of the State.

This is how the Customs authorities regarded or had an opportunity to estimate the importation of stone and dust from the moon into their territory. The information on customs 
declarations of imports from the celestial body by astronaut contains the idea that each State independently regulates its relations in customs affairs concerning the movement of goods across the customs border, and goods of space origin are no exception here. While customs law issues are not addressed by the US Commercial Space Launch Competitiveness Act, they generally reflect its ideas.

However, is this position justified? It seems that it is not. Properly established customs policy is a reliable mechanism for securing the protection of the earth's resource markets from "space dumping" and for shaping the positive impact of the space mining industry on the entire population of planet Earth. However, an individual State pursuing such activities, the space commercial entities registered therein, as mentioned above, will not be interested in a fair solution to these problems. On the other hand, space resources should be considered first and foremost as being imported to planet Earth and only after that as being released into the territory of a particular State.

Therefore, a global administrator should be in charge of formulating and implementing customs policy for the importation of space resources. This will enable to apply the tools known in customs law.

The super global projects are brand new and additional to the already implemented space activities (e.g. monitoring of the Earth's environment, telecommunication systems, etc.). They are urgent for the unification of the world community, the transition to a new quality of the process of space exploration aimed at the survival and development of mankind in the paradigm of the ultimate strategic perspective towards the Earth's protection, terrestrial civilization and space humanity establishment [Krichevsky, 2018: 101].

\section{Conclusion}

The mining in outer space will begin in the near future. These activities are not regulated by the provisions of international law and begins to be governed by the provisions of national law. This situation can lead to various (not just legal) conflicts over the property rights of extracted resources. In addition, the uncontrolled importation of minerals on planet Earth poses a serious threat to its economy. It is possible to counteract these challenges by using an instrument of global administrative law.

The creation of a global administrator in space resources should be central. The legal basis for its implementation is not significant. It shall address several important factors.

First, the global space administrator should be a completely independent entity focused on protecting and safeguarding the interests of planet Earth and its population in accordance with the Treaty on Principles Governing the Activities of States in the Exploration and Use of Outer Space, including the Moon and Other Celestial Bodies, as well as other international space law regulations.

Second, complete transparency and control of its activities should be ensured. This is required because the shift of regulatory influence from national to global bodies has initially complicated the mechanism of ensuring accountability and control of the latter, significantly reducing their responsibility to those who are subject to administrative influence. However, to address these challenges, the activities of global administrators get increasing regulation by administrative and legal standards, which include requirements for transparency, participation, validity of decisions, and the like. This should ensure accountability of the administrator and feedback. 
Third, the global administrator shall be empowered with law-making authorities. The normative acts issued by him shall be obligatory for all entities engaged in space resources activities.

Fourth, special means of ensuring the authority of the global administrator should exist. This can be space arbitration, databases accessible to all space businesses, the promotion of space entrepreneurship, and the protection of space entrepreneurs' interests in national and international bodies.

Fifth, a global administrator in space resources shall be given some supervisory powers.

Properly organized customs can become one of the main mechanisms for securing the common interests of planet Earth's inhabitants and for controlling and regulating the impact on the world economy of importing space mineral deposits to our planet. It may include:

- limits for the import of specific minerals to Earth based on the needs and capabilities of local markets;

- quotas for the import of minerals during a certain period. It is difficult to determine the quota period without serious calculations. On the one hand, it should take into account the complexity of extracting and transporting goods from space, and on the other hand, it should ensure the dynamism and timeliness of regulation. The electronic tender for firms admitted as able to carry out exploitation and extraction independently is optimal for implementing quotas;

- customs duties on imports of space minerals and goods produced in outer space. This instrument will ensure that the prices of imported minerals are in line with the prices of minerals of the terrestrial markets. The purpose of customs duties should be not to collect maximum funds from the entrepreneur, but to protect the world economy from sharp shocks and price fluctuations;

- control of the importation of minerals and goods produced in outer space to Earth. The conformity of total goods delivered to the size of supply quotas shall be subject to control. Furthermore, characteristics of the goods, which may be dangerous to the population of the earth, shall be subject to inspection.

The application of these instruments requires a small number of workers, because in any case a rather limited range of business entities will be engaged in space resources activities for a long period.

For proceeds from the collection of duties and quotas for the supply of minerals to the earth, the manner of their use should be determined by an international treaty on establishing a global administrator. Reasonably, they shall be in accordance with Article 1 of the Outer Space Treaty. That is, the funds from extraction of minerals shall be used for the benefit of all countries, irrespective of their degree of economic or scientific development. Independently the global administrator is not capable of ensuring such missions to be performed that is why they should be implemented by recognized international organizations.

Therefore, three important questions remain open.

First, how should planetary (space) customs law relate to national customs law, or whether the minerals of space origin are to be subject to customs controls and customs payments at the national level?

Second, how and in what order should control over the activities of the global space resource administrator be implemented?

Third, how should relations be established between the global administrator and the States, which independently, without the involvement of private entities, will extract minerals in outer space (apparently the role can be assumed by the PRC)? 


\section{References}

A/AC.105/C.2/2016/TRE/L.1. Draft report. Annex I. Report of the Chair of the Working Group on the Status and Application of the Five United Nations Treaties on Outer Space, 2016. https://www.unoosa.org/res/oosadoc/data/documents/2016/aac_105c_2tre/ aac_105c_22016trel_1_0 html/AC105_C2_2016_TRE_L01E.pdf

A/AC.105/C.2/2018/CRP.18. The Hague Space Resources Governance Working Group. Information provided by the Netherlands. April 12, 2018 / Committee on the Peaceful Uses of Outer Space. Legal Subcommittee. Fifty-seventh session. Vienna, 9-20 April 2018. http://www.unoosa.org/res/oosadoc/data/documents/2018/aac_105c_22018crp/ aac_105c_22018crp_18_0_html/AC105_C2_2018_CRP18E.pdf

Benett, Gary L. Proposed Principles on the Use of Nuclear Power Sources in Space. Proceedings on the 23rd Intersociety Energy Conversion Engineering Conference, 1988. Vol.3. P. 23-27. http://fas.org/nuke/space/propprin.pdf

Dimitropoulos, Georgios. Global Administrative Order: Towrds a Typology of Administrative Levels and Functions in the Global Legal Order. European Review of Public Law. 2011. Vol. 23, \# 1 (79). https://www.academia.edu/1330126/Global_Administrative_Order. Towrds_a_Typology_of_Administrative_Levels_and_Functions in the Global Legal_Order

de Selding, Peter B. New U.S. Space Mining Law's Treaty Compliance May Depend on Implementation. SpaceNews. December 9, 2015. http://spacenews.com/u-scommercial-space-acts-treaty-compliance-may-depend-on-implementation/\#sthash. r5TiS1gK.dpuf

Draft Building Blocks for the Development of an International Framework on Space resource Activities. Leiden University. Institute of Air and Space Law, 2018 https:// www.universiteitleiden.nl/binaries/content/assets/rechtsgeleerdheid/instituutvoor-publiekrecht/lucht--en-ruimterecht/space-resources/draft-building-blocks.pd f?fbclid=IwAR3nZ2uEk25wstw7wljSb51wrnbunb0oFBYONkK7IzEgBhm8wgu Cshhk1cU

GDP (current US\$) World Bank national accounts data, and OECD National Accounts data files. The World Bank, 2019. https://data.worldbank.org/indicator/NY.GDP.MKTP. CD?year_high_desc $=$ true

Kingsbury, Benedict and Donaldson, Megan. Global Administrative Law. Oxford Public International Law. Oxford University Press, 2011. http://opil.ouplaw.com

Kingsbury, Benedict and Stewart, Richard B. Legitimacy and Accountability in Global Regulatory Governance: The Emerging Global Administrative Law and The Design and Operation of Administrative Tribunals of International Organizations, 2016. http://iilj. org/wp-content/uploads/2016/08/Kingsbury-Stewart-Legitimacy-and-Accountabilityin-Global-Regulatory-Governance-1.pdf

Khvostik, Ye. Asteroid fever on the way. Komersant, 6.05.2018. https://www.kommersant.ru/ doc/3618726

Koerth-Baker, Maggie. Who Makes the Rules for Outer Space? NovaNext. November 30, 2015. http://www.pbs.org/wgbh/nova/next/space/space-law/

Krichevsky, Sergey. Super Global Projects and Environmentally Friendly Technologies Used in Space Exploration: Realities and Prospects of the Space Age. Philosophy and 
Cosmology, Vol. 20. 2018: 92-105. https://doi.org/10.29202/phil-cosm/20/8

López, Escarcena Sebastián. Investment Disputes Oltre lo Stato: on Global Administrative Law, and Fair and Equitable Treatment. Boston College Law Review, 2018. Vol. 59, \# 8. https://www.academia.edu/38200687/Investment_Disputes_oltre_lo_stato_On_ Global_Administrative_Law_and_Fair_and_Equitable_Treatment?email_work card=view-paper

Luxembourg Space Agency, 2019. http://www.spaceresources.public.lu/en/index.html (дата звертання: 25.09.2019).

Masson-Zwaan, Tanja and Bob Richards. International Perspectives on Space Resource Rights. SpaceNews. December 8, 2015. http://spacenews.com/op-ed-internationalperspectives-on-space-resource-rights/\#sthash.qUo6j9VQ.dpuf

Oduntan, Gbenga. Who owns space? US asteroid-mining act is dangerous and potentially illegal. The Conversation. November 25, 2015. https://theconversation.com/whoowns-space-us-asteroid-mining-act-is-dangerous-and-potentially-illegal-51073

Pugach, Victoriya. The Problem of State Subjectivity in the Optics of the Concept of Global Administrative Law. Actual Problems of Administrative Law (To the 95th Anniversary of RS Pavlovsky's Birth): Proceedings of the International Scientific and Practical Conference, Kharkiv, September 26, 2019. - Kherson. Helvetika Publishing House, 2019. pp. 75-77

Popova, Svetlana "The Hague Model" of legal regulation of activities in the field of space resources and the prospects for the transformation of international space law. Space Research, 2018. №. 2. P. 144 — 174. https://doi.org/10.7256/2453-8817.2018.2.28631

Rummel, John D. One Small Step for Space Resources. SpaceNews. December, 9. 2015. http:// spacenews.com/op-ed-the-next-steps-for-space-resources/\#sthash.rD4m6gnw. 